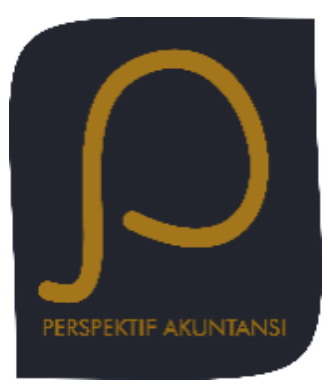

Perspektif Akuntansi

Volume 4 Nomor 1 (Februari 2021), hal. 35-58

ISSN: 2623-0194 (Print), 2623-0186 (Online)

Copyright(C) The Authors(s). All Rights Reserved

Center for Accounting Development and Research (CARD)

Fakultas Ekonomika dan Bisnis,

Universitas Kristen Satya Wacana

DOI: https://doi.org/10.24246/persi.vXiX.p35-58

http://ejournal.uksw.edu/persi

\title{
Pendeteksian Kecurangan Pelaporan Keuangan Melalui Fraud Pentagon Framework
}

Melia Bakti Milenia Mintara ${ }^{1}$

Aprina Nugrahesthy Sulistya Hapsari

Universitas Kristen Satya Wacana

Received

06/04/2021

Abstract. This study aims to examine the effect of fraud pentagon

Revised

20/04/2021 to detect the possibility of fraudulent financial reporting on mining companies listed in Indonesia Stock Exchange (IDX) from 2016 to 2018. Data was collected from companies' annual reports from IDX's website and companies' website. This study is a quantitative study and used multiple linear regression analysis. The result shows

Accepted

$21 / 04 / 2021$ that financial targets, nature of industry, and change of auditor have a positive significant effect on fraudulent financial reporting. While financial stability, external pressure, uneffective monitoring, rationalization, change in directors, and number of CEO's pictures have no effect on fraudulent financial reporting.

Keywords: fraud pentagon, fraudulent financial statement, fraud, earnings management

\begin{abstract}
Abstrak. Penelitian ini bertujuan untuk menguji pengaruh fraud pentagon dalam mendeteksi kemungkinan terjadinya kecurangan laporan keuangan pada perusahaan pertambangan yang terdaftar di Bursa Efek Indonesia (BEI) periode 2016 sampai 2018. Data diperoleh dari laporan tahunan yang terdapat pada website BEI dan website perusahaan. Penelitian ini merupakan penelitian kuantitatif dan menggunakan analisis regresi linear berganda. Hasil penelitian ini menunjukkan bahwa target keuangan, sifat industri, dan pergantian auditor memiliki pengaruh positif signifikan terhadap kecurangan laporan keuangan. Namun stabilitas keuangan, tekanan eksternal, ketidakefektifan pengawasan, rasionalisasi, pergantian direksi, dan jumlah foto CEO tidak berpengaruh pada kecurangan laporan keuangan.
\end{abstract}

Kata kunci: fraud pentagon, kecurangan laporan keuangan, kecurangan, manajemen laba

1232017015@student.uksw.edu 


\section{Pendahuluan}

PT Asuransi Jiwasraya menyita perhatian masyarakat dengan skandal kecurangan laporan keuangan yang dilakukannya pada awal tahun 2020. Hal tersebut dilakukan dengan cara membukukan laba semu sejak 2006 yang kemudian terungkap dalam hasil investigasi BPK (Halim, 2020). Kasus ini juga melibatkan peran akuntan PT Asuransi Jiwasraya yang melakukan rekayasa pada laporan keuangan secara berkesinambungan (Ulya, 2020). Kejanggalan juga ditemukan pada laporan keuangan PT Garuda Indonesia periode 2018. Dua komisaris Garuda Indonesia menolak untuk memberikan tanda tangan dan menganggap bahwa laporan keuangan tersebut tidak sesuai dengan Pernyataan Standar Akuntansi Keuangan (PSAK) (Pratiwi, 2019). Pada laporan keuangan tersebut tercatat laba bersih senilai USD 809.846 yang menunjukkan peningkatan tajam dibandingkan tahun 2017 yang mengalami rugi sebesar USD 216,58 juta (Kurnia, 2019). Selain itu ada juga kasus perusahaan properti yaitu PT Hanson International yang terbukti melakukan manipulasi laporan keuangan tahun 2016 (Idris, 2020). Perusahaan ini mencatatkan penjualan kavling siap bangun (kasiba) senilai Rp732 miliar sehingga pendapatannya naik drastis dibandingkan tahun sebelumnya.

Laporan keuangan merupakan bentuk pertanggungjawaban manajemen kepada para pemangku kepentingan atau stakeholder. Laporan keuangan menggambarkan kondisi keuangan dan operasional perusahaan selama satu periode yang informasi tersebut sangat penting karena dapat mempengaruhi pengambilan keputusan para pemangku kepentingan (Agusputri \& Sofie, 2019). Laporan keuangan harus disusun dengan jujur dan sesuai dengan Standar Akuntansi Keuangan (SAK) yang ditetapkan oleh Ikatan Akuntan Indonesia (IAI). Namun dalam praktiknya tidak semua manajemen perusahaan sadar akan pentingnya laporan keuangan yang bersih dan bebas dari kecurangan (Yesiariani \& Rahayu, 2017). Hal ini dikarenakan perusahaan ingin menunjukkan citra yang baik bagi para pemangku kepentingan. Apabila informasi dalam laporan keuangan disajikan untuk memenuhi kepentingan pihak tertentu, maka dapat menimbulkan risiko terjadinya kecurangan atau fraud karena tidak menunjukkan kondisi yang sebenarnya. Kecurangan dalam penyajian laporan keuangan ini bisa juga disebut dengan istilah fraudulent financial reporting.

Penelitian mengenai kecurangan laporan keuangan sebelumnya pernah dilakukan oleh Noble (2019) yang menggunakan variabel fraud diamond untuk mendeteksi kecurangan laporan keuangan perusahaan pertambangan selama periode 20142016. Hasilnya adalah tekanan dan rasionalisasi berpengaruh terhadap kecurangan laporan keuangan, namun variabel kesempatan dan kompetensi tidak berpengaruh terhadap kecurangan laporan keuangan. Putriasih et al. (2019) juga meneliti kecurangan laporan keuangan menggunakan variabel fraud diamond pada perusahaan manufaktur yang terdaftar di Bursa Efek Indonesia (BEI) periode 20132015. Hasilnya adalah baik secara simultan maupun parsial semua variabel fraud diamond dapat digunakan untuk mendeteksi adanya kecurangan pada laporan keuangan. 
Kemudian, Septriani dan Handayani (2018) meneliti kecurangan laporan keuangan dengan analisis fraud pentagon. Objek yang digunakan adalah perusahaan perbankan dan manufaktur yang terdaftar di BEI periode 2013-2016. Hasil yang diperoleh menunjukkan bahwa financial stability, external pressure, pergantian auditor dan pergantian dewan direksi berpengaruh terhadap kecurangan laporan keuangan perusahaan manufaktur, sedangkan financial target, financial stability, ineffective monitoring dan rationalization berpengaruh terhadap kecurangan laporan keuangan perusahaan perbankan. Selanjutnya Selano et al. (2017) meneliti faktor-faktor yang berpengaruh pada kecenderungan melakukan kecurangan laporan keuangan dengan objek perusahaan property, real estate and building yang terdaftar di BEI tahun 20132015. Hasil yang diperoleh menunjukkan bahwa variabel financial stability dan external pressure tidak berpengaruh terhadap kecenderungan untuk melakukan kecurangan laporan keuangan.

Lain halnya dengan variabel financial target, nature of industry, ineffective monitoring, dan rationalization yang berpengaruh terhadap kecenderungan untuk melakukan kecurangan laporan keuangan. Adapun Handoko dan Ramadhani (2017) meneliti tentang pengaruh komite audit, keahlian keuangan, dan ukuran perusahaan terhadap kecurangan laporan keuangan dengan objek perusahaan manufaktur yang terdaftar di BEI tahun 2013-2015. Hasil penelitian tersebut menunjukkan bahwa kecurangan laporan keuangan tidak dipengaruhi oleh komite audit independen dan ukuran perusahaan, sedangkan keahlian keuangan komite audit berpengaruh terhadap kecurangan laporan keuangan.

Berdasarkan fenomena dan latar belakang yang telah diuraikan di atas, penelitian ini memiliki tujuan untuk menguji pengaruh dari elemen-elemen fraud pentagon untuk mendeteksi kemungkinan terjadinya kecurangan laporan keuangan pada perusahaan pertambangan yang terdaftar di BEI. Berbeda dengan penelitian-penelitian sebelumnya, variabel independen penelitian ini menggunakan elemen-elemen fraud pentagon yang terdiri dari tekanan (pressure), kesempatan (opportunity), rasionalisasi (rationalization), kompetensi (competence), dan arogansi (arrogance). Selain itu periode laporan keuangan yang diamati pada penelitian ini adalah tahun 2016-2018. Alasan memilih perusahaan pertambangan sebagai objek adalah karena menurut Association of Certified Fraud Examiners (ACFE) (2020) melalui Report to the Nations 2020 menunjukkan bahwa sektor pertambangan mengalami kerugian terbesar akibat kasus kecurangan yaitu sebesar USD 475.000. Selain itu penelitian ini menggunakan objek laporan keuangan karena ACFE (2016) melalui Survei Fraud Indonesia tahun 2016 menyatakan bahwa banyak kasus kecurangan laporan keuangan di Indonesia yang masih belum terungkap, misalnya penipuan informasi pajak dan penipuan informasi di bursa efek.

Penelitian ini memiliki manfaat teoritis terkait kecurangan dalam laporan keuangan dan manfaat praktis bagi para pengguna laporan keuangan. Manfaat tersebut adalah dapat memberikan informasi mengenai faktor-faktor di dalam kerangka kerja fraud pentagon yang dapat mendeteksi kecurangan laporan keuangan pada perusahaan pertambangan yang terdaftar di BEI selama periode 2016-2018. Informasi tersebut 
dapat dipakai sebagai salah satu bahan pertimbangan dalam pengambilan keputusan. Selain itu penelitian ini juga dapat dijadikan referensi dan menambah literatur khususnya di bidang audit keperilakuan yang membahas mengenai faktor-faktor kerangka kerja fraud pentagon yang dapat mendeteksi kemungkinan terjadinya kecurangan laporan keuangan.

\section{Telaah Pustaka}

\section{Agency Theory}

Agency theory merupakan sebuah teori yang berkaitan dengan masalah antara prinsipal dan agen mengenai pemisahan kepemilikan dan kontrol atas suatu perusahaan (Jensen \& Meckling, 1976). Hubungan keagenan timbul dari kontrak ketika salah satu pihak (prinsipal) memerintahkan orang lain (agen) untuk melakukan suatu hal dan mendelegasikan wewenang kepada agen tersebut untuk mengambil keputusan (Jensen \& Meckling, 1976). Dalam suatu perusahaan, pemegang saham menginginkan hasil pengembalian yang tinggi dari investasinya, sedangkan manajer memiliki kepentingan tersendiri untuk memperoleh hasil atau kompensasi yang lebih tinggi atas kinerjanya (Bawakes et al., 2018). Hal ini dapat menimbulkan konflik karena masing-masing pihak memiliki kepentingan yang berbeda. Selain itu Kurniawansyah et al. (2019) mengatakan bahwa konflik tersebut dapat menimbulkan beberapa masalah. Pertama, prinsipal tidak dapat mengawasi secara penuh agen tersebut melakukan tugasnya secara jujur atau tidak. Kedua, masalah mengenai pembagian risiko yang muncul ketika prinsipal dan agen memiliki perilaku yang berbeda ketika menghadapi risiko.

Agency theory digunakan dalam penelitian ini karena perbedaan kepentingan antara pemegang saham dan manajer dapat menyebabkan manajer melakukan kecurangan dalam membuat laporan keuangan. Pemegang saham tidak dapat mengawasi secara penuh ketika manajer menjalankan tugasnya dalam mengelola perusahaan, sehingga dapat menimbulkan celah bagi manajer untuk melakukan kecurangan karena pemegang saham juga tidak mengetahui informasi mengenai perusahaan sedetail manajer. Selain itu manajer juga dapat melakukan kecurangan dalam pembuatan laporan keuangan demi kepentingannya sendiri supaya kinerjanya terlihat bagus dan selalu mencapai target. 


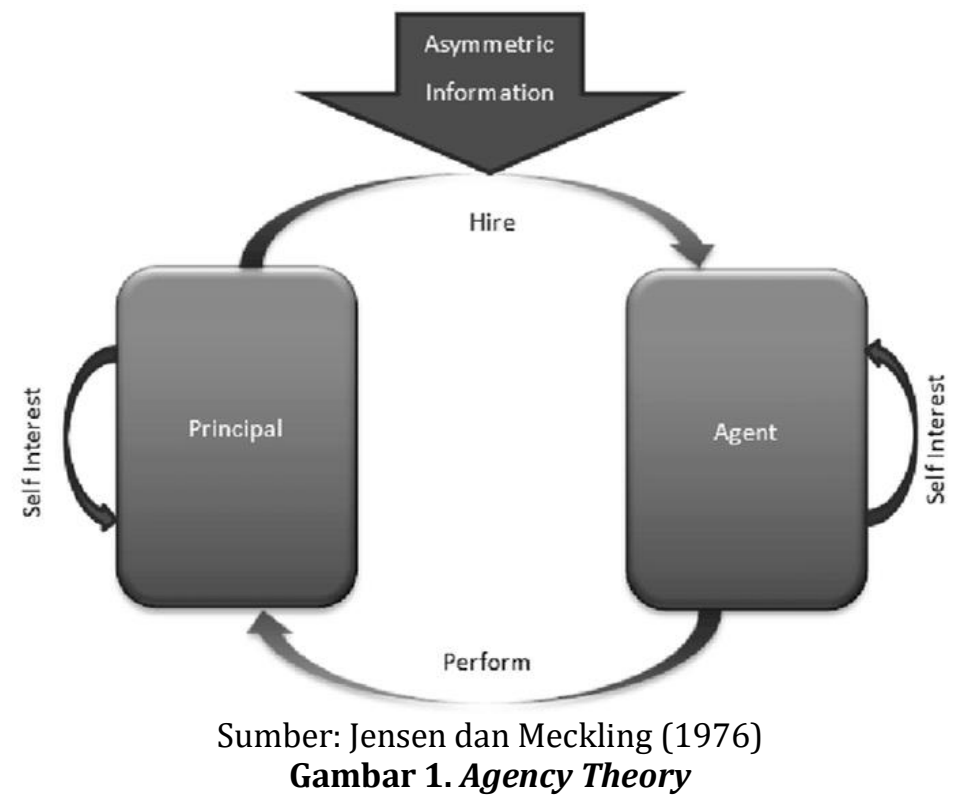

\section{Kecurangan (Fraud)}

Karyono (2013) melalui bukunya Forensic Fraud mendefinisikan kecurangan sebagai penyimpangan dan perbuatan ilegal atau melanggar hukum yang dilakukan secara sengaja untuk mencapai tujuan tertentu, misalnya dengan cara menipu atau memberikan gambaran yang keliru kepada pihak lain, dan dapat dilakukan oleh pihak baik dari dalam maupun luar organisasi. Albrecht et al. (2012) dalam bukunya Fraud Examination berpendapat bahwa kecurangan adalah tindakan penipuan dengan sengaja yang dilakukan seseorang atau lebih secara sadar dan tidak ada unsur paksaan serta dapat merugikan orang lain (korban) dan menguntungkan pelakunya. Selain itu ACFE (2016) melalui Survei Fraud Indonesia tahun 2016 menyatakan bahwa kecurangan adalah tindakan melawan hukum secara sengaja untuk suatu tujuan tertentu (misalnya memanipulasi atau menyajikan laporan yang keliru kepada pihak lain) dan dilakukan oleh pihak internal maupun eksternal organisasi untuk memperoleh keuntungan pribadi atau kelompok dan dapat merugikan pihak lain baik secara langsung maupun tidak langsung. Definisi kecurangan yang dipakai dalam penelitian ini adalah menurut (ACFE, 2016).

ACFE (2016) membagi kecurangan menjadi beberapa jenis, yaitu asset misappropriation, fraudulent statements, dan corruption. Kecurangan laporan keuangan atau fraudulent financial reporting termasuk dalam kategori fraudulent statements. Definisi kecurangan laporan keuangan menurut ACFE (2020) adalah suatu tindakan yang dilakukan karyawan secara sengaja untuk menyebabkan salah saji atau kelalaian informasi bersifat material dalam pembuatan laporan keuangan organisasi. Kecurangan laporan keuangan dapat dilakukan dengan menyajikan nilai lebih tinggi dari yang seharusnya (overstatements) atau menyajikan nilai lebih rendah dari yang seharusnya (understatements). Contoh salah saji yang biasa dilakukan adalah melebihkan jumlah aset, penjualan, laba, dan juga mengurangi jumlah hutang, biaya, dan kerugian (Noble, 2019). 
Kecurangan laporan keuangan juga dilakukan dengan tujuan untuk menarik perhatian investor, memperoleh harga jual yang lebih tinggi untuk akuisisi, mencapai tujuan perusahaan, menghilangkan persepsi negatif dalam pasar, dan dapat menerima kompensasi lebih tinggi atas kinerja yang baik (Wilopo, 2014). Tandatanda atau gejala adanya kecurangan laporan keuangan menurut Albrecht et al. (2012) yaitu adanya anomali akuntansi, pengendalian internal yang lemah, anomali analisis, gaya hidup yang berlebihan, perilaku yang tidak biasa, dan komplain. Pada penelitian ini kecurangan laporan keuangan akan diproksikan dengan manajemen laba yang dihitung dengan nilai discretionary accrual menggunakan model yang diperkenalkan oleh Jones (1991) yang telah dimodifikasi Dechow et al. (2015).

\section{Fraud Pentagon}

Awalnya Cressey (1953) memperkenalkan sebuah kerangka kerja untuk melihat faktor-faktor yang mendorong seseorang melakukan kecurangan. Kerangka kerja ini disebut dengan istilah fraud triangle yang terdiri dari tekanan (pressure), kesempatan (opportunity), dan rasionalisasi (rationalization). Kerangka kerja ini kemudian dikembangkan oleh Wolfe dan Hermanson (2004) menjadi fraud diamond dengan menambahkan faktor baru yaitu kemampuan (capability). Kemampuan dalam hal ini adalah kemampuan untuk mengetahui dan memanfaatkan kesempatan melalui posisi yang dimiliki dalam perusahaan (Artani \& Wetra, 2017). Selanjutnya kerangka kerja ini kembali dikembangkan oleh Horwath (2011) menjadi fraud pentagon. Faktor tambahan dalam fraud pentagon ini adalah kompetensi (competence) yang bermakna sama dengan kemampuan (capability), dan arogansi (arrogance) yang merupakan sikap seseorang yang menganggap segala kebijakan dan peraturan tidak berlaku bagi dirinya sehingga tidak merasa bersalah apabila melakukan kecurangan (Bawakes et al., 2018).

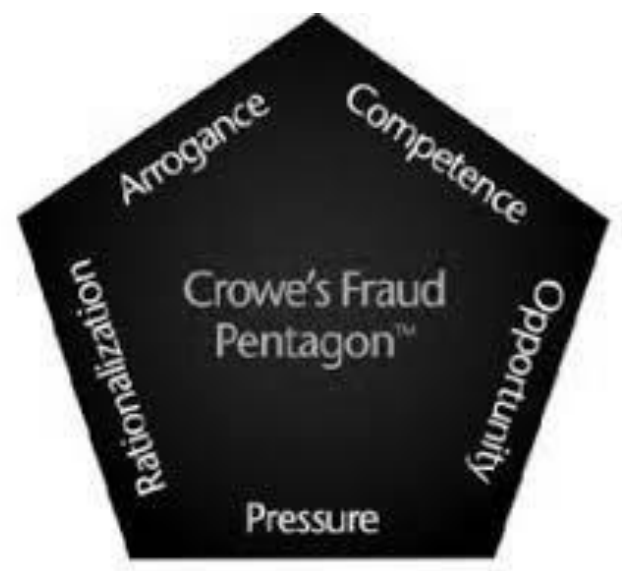

Sumber: Horwath (2011)

\section{Gambar 2. Kerangka Kerja Fraud Pentagon}

Pada penelitian ini faktor-faktor dalam kerangka kerja fraud pentagon akan diproksikan menggunakan beberapa variabel. Tekanan akan diproksikan menggunakan variabel target keuangan, stabilitas keuangan, dan tekanan eksternal. Kesempatan diproksi dengan variabel ketidakefektifan pengawasan dan sifat industri. Rasionalisasi diproksi menggunakan variabel pergantian auditor dan 
rasionalisasi. Kompetensi diproksi menggunakan variabel pergantian direksi. Faktor terakhir yaitu arogansi diproksikan menggunakan variabel jumlah foto CEO.

\section{Pengaruh Target Keuangan (Financial Target) terhadap Kecurangan Laporan Keuangan}

Target keuangan merupakan target yang ditetapkan oleh direksi mengenai kinerja keuangan yang harus dicapai oleh perusahaan, misalnya laba (Agusputri \& Sofie, 2019). Apabila kondisi keuangan perusahaan sedang menurun, target keuangan dapat menjadi tekanan bagi pihak manajemen. Tekanan akibat target keuangan ini mengakibatkan manajer akan melakukan berbagai cara demi tercapainya target laba yang diberikan, termasuk melakukan kecurangan dalam pembuatan laporan keuangan. Pada penelitian ini target keuangan dihitung menggunakan Return on Asset (ROA) karena dapat mengukur tingkat laba yang mampu dihasilkan perusahaan. Selain itu hasil penelitian Putriasih et al. (2019) yang menggunakan objek perusahaan manufaktur dan penelitian Noble (2019) yang menggunakan objek perusahaan pertambangan menunjukkan hasil bahwa faktor tekanan yang diproksikan dengan target keuangan berpengaruh positif terhadap kecurangan laporan keuangan. Oleh karena itu, dapat dirumuskan hipotesis:

$\boldsymbol{H}_{1}$ : Target keuangan (financial target) berpengaruh positif terhadap kecurangan laporan keuangan.

\section{Pengaruh Stabilitas Keuangan (Financial Stability) terhadap Kecurangan Laporan Keuangan}

Stabilitas keuangan merupakan kondisi keuangan perusahaan yang stabil (Agusputri \& Sofie, 2019). Umumnya perusahaan menginginkan kondisi keuangannya meningkat atau setidaknya tidak turun (stabil). Investor lebih suka berinvestasi pada perusahaan yang keuangannya stabil karena risiko yang muncul dinilai lebih rendah dari perusahaan yang keuangannya fluktuatif. Stabilitas keuangan dapat menjadi tekanan bagi pihak manajemen untuk menjaga kestabilan keuangan perusahaan agar tidak menurun. Ketika kondisi keuangan sedang tidak stabil, manajemen dapat menutupinya dengan melakukan kecurangan laporan keuangan. Hal ini didukung dengan hasil penelitian Sihombing dan Rahardjo (2014) serta Bawakes et al. (2018) yang menyatakan bahwa stabilitas keuangan berpengaruh positif terhadap kecurangan laporan keuangan. Pada penelitian ini stabilitas keuangan diukur dengan jumlah perubahan total aset dari tahun ke tahun. Hal ini karena Bawakes et al. (2018) berpendapat bahwa banyaknya aset yang dimiliki perusahaan menjadi daya tarik bagi para pemangku kepentingan. Berdasarkan uraian di atas maka dapat dirumuskan hipotesis:

$\boldsymbol{H}_{2}$ : Stabilitas keuangan (financial stability) berpengaruh positif terhadap kecurangan laporan keuangan. 


\section{Pengaruh Tekanan Eksternal (External Pressure) terhadap Kecurangan Laporan Keuangan}

Tekanan eksternal merupakan tekanan yang dialami manajemen untuk memenuhi harapan atau persyaratan dari pihak ketiga (Yesiariani \& Rahayu, 2017). Dalam menjalankan kegiatan operasionalnya, perusahaan membutuhkan sumber pendanaan dari pihak eksternal seperti pinjaman bank. Pada penelitian ini tekanan eksternal dihitung menggunakan rasio leverage, yaitu perbandingan antara total liabilitas dan total aset perusahaan yang dapat menunjukkan tingkat risiko kredit suatu perusahaan. Jika rasio leverage perusahaan tinggi maka dapat dikatakan perusahaan memiliki hutang yang banyak dan risiko kreditnya tinggi. Hal ini dapat mengakibatkan terjadinya kecurangan laporan keuangan misalnya dengan menurunkan jumlah hutang yang dimiliki supaya dapat memperoleh pinjaman dari pihak eksternal. Penelitian Yesiariani dan Rahayu (2017) serta Putriasih et al. (2019) memperoleh hasil bahwa tekanan eksternal berpengaruh positif dan dapat digunakan untuk mendeteksi kecurangan laporan keuangan. Berdasarkan penjelasan di atas dapat dirumuskan hipotesis:

$\boldsymbol{H}_{3}$ : Tekanan eksternal (external pressure) berpengaruh positif terhadap kecurangan laporan keuangan.

\section{Pengaruh Ketidakefektifan Pengawasan (Ineffective Monitoring) terhadap Kecurangan Laporan Keuangan}

Ketidakefektifan pengawasan merupakan kondisi yang menunjukkan bahwa sistem pengawasan internal perusahaan tidak berjalan dengan efektif (Septriani \& Handayani, 2018). Hal ini dapat membuka kesempatan untuk melakukan kecurangan laporan keuangan karena manajemen merasa tidak diawasi dengan ketat (Agusputri \& Sofie, 2019). Dalam penelitian ini ketidakefektifan pengawasan dihitung menggunakan proporsi antara jumlah dewan komisaris independen dengan jumlah total dewan komisaris. Penelitian Agusputri dan Sofie (2019) memperoleh hasil bahwa ketidakefektifan pengawasan memiliki pengaruh positif terhadap laporan keuangan, sehingga dapat dirumuskan hipotesis:

$\boldsymbol{H}_{4}$ : Ketidakefektifan pengawasan (ineffective monitoring) berpengaruh positif terhadap kecurangan laporan keuangan.

\section{Pengaruh Sifat Industri (Nature of Industry) terhadap Kecurangan Laporan Keuangan}

Sifat industri merupakan keadaan ideal perusahaan dalam suatu industri (Yesiariani \& Rahayu, 2017). Pada laporan keuangan terdapat beberapa akun yang saldonya ditentukan berdasarkan estimasi, misalnya piutang tak tertagih dan persediaan usang (Septriani \& Handayani, 2018). Hal ini dapat meningkatkan kesempatan melakukan kecurangan laporan keuangan karena manajemen dapat memainkan akun-akun tersebut dengan subjektif supaya terlihat ideal. Perusahaan akan terlihat ideal jika jumlah piutangnya kecil dan pemasukan kasnya besar (Sihombing \& Rahardjo, 2014). Dalam penelitian ini sifat industri akan dihitung menggunakan rasio perubahan 
piutang perusahaan. Penelitian Sihombing dan Rahardjo (2014) mendapatkan hasil bahwa sifat industri memiliki pengaruh positif terhadap kecurangan laporan keuangan, sehingga dirumuskan hipotesis:

$\boldsymbol{H}_{5}$ : Sifat industri (nature of industry) berpengaruh positif terhadap kecurangan laporan keuangan.

\section{Pengaruh Pergantian Auditor (Change in Auditor) terhadap Kecurangan Laporan Keuangan}

Laporan keuangan perusahaan harus diaudit oleh auditor eksternal untuk mendapatkan opini mengenai wajar tidaknya laporan keuangan tersebut. Pihak manajemen akan selalu berusaha mendapatkan atau mempertahankan opini wajar. Rasionalisasi diproksikan dengan pergantian auditor karena pendapat auditor mengenai wajar tidaknya laporan keuangan merupakan rasionalisasi auditor terhadap kecurangan yang dilakukan perusahaan. Perusahaan melakukan pergantian auditor atau kantor akuntan publik bisa saja bertujuan untuk menghapuskan jejak kecurangan perusahaan yang telah diketahui auditor sebelumnya (Agusputri \& Sofie, 2019). Selain itu perusahaan dapat juga mengganti auditornya untuk mengurangi kemungkinan pendeteksian kecurangan oleh auditor yang lama (Tiffani \& Marfuah, 2009). Hasil penelitian Faradiza dan Suyanto (2017) serta Wahyuni dan Budiwitjaksono (2017) menunjukkan adanya pengaruh positif pergantian auditor terhadap kecurangan laporan keuangan perusahaan. Semakin banyak melakukan pergantian auditor memungkinkan semakin tinggi adanya kecurangan laporan keuangan, sehingga dapat dirumuskan hipotesis:

$\boldsymbol{H}_{6}:$ Pergantian auditor (change in auditor) berpengaruh positif terhadap kecurangan laporan keuangan.

\section{Pengaruh Rasionalisasi (Rationalization) terhadap Kecurangan Laporan Keuangan}

Definisi rasionalisasi menurut Albrecht et al. (2012) melalui bukunya "Fraud Examination" adalah suatu pembenaran atau alasan yang salah terhadap suatu perilaku yang salah. Manajemen laba merupakan awal terjadinya kecurangan laporan keuangan dan merupakan akibat dari adanya prinsip akrual yang telah disepakati dalam menyusun laporan keuangan (Septriani \& Handayani, 2018). Prinsip akrual dapat digunakan pihak manajemen untuk mengubah laba sehingga dapat termasuk sebagai kecurangan laporan keuangan (Sihombing \& Rahardjo, 2014). Dalam penelitian ini rasionalisasi dihitung menggunakan rasio total akrual per total aset. Semakin tinggi rasio total akrual per total aset maka semakin tinggi rasionalisasi terhadap kecurangan laporan keuangan. Pernyataan ini sejalan dengan hasil penelitian Yesiariani dan Rahayu (2017) bahwa rasionalisasi berpengaruh positif terhadap kecurangan laporan keuangan, sehingga diperoleh hipotesis:

$\boldsymbol{H}_{7}$ : Rasionalisasi (rationalization) berpengaruh positif terhadap kecurangan laporan keuangan. 


\section{Pengaruh Pergantian Direksi (Change of Director) terhadap Kecurangan Laporan Keuangan}

Wolfe dan Hermanson (2004) mengatakan bahwa kecurangan tidak akan terjadi tanpa orang yang memiliki kompetensi untuk melakukan setiap detail kecurangan dengan baik. Pada penelitian ini kompetensi diproksikan dengan banyaknya pergantian direksi yang dilakukan perusahaan. Direksi merupakan orang yang berpengaruh dalam perusahaan dan membuat kebijakan. Perusahaan melakukan pergantian direksi sebagai upaya untuk memperbaiki kinerja para direksi yang sebelumnya dan merekrut direksi baru yang dianggap lebih kompeten (Septriani \& Handayani, 2018). Semakin banyak pergantian direksi maka semakin sedikit kecurangan laporan keuangan yang dilakukan karena direksi semakin kompeten untuk mengawasi kinerja manajemen. Hal ini didukung dengan penelitian Septriani dan Handayani (2018) yang menunjukkan hasil adanya pengaruh negatif pergantian direksi terhadap kecurangan laporan keuangan perusahaan manufaktur. Berdasarkan uraian di atas dapat dirumuskan hipotesis:

$\boldsymbol{H}_{8:}$ Pergantian direksi (change in director) berpengaruh negatif terhadap kecurangan laporan keuangan.

\section{Pengaruh Jumlah Foto CEO (Frequent Number of CEO Picture) terhadap Kecurangan Laporan Keuangan}

Banyaknya foto CEO yang terdapat dalam laporan keuangan tahunan perusahaan dapat menunjukkan tingkat arogansi CEO tersebut (Yusof, 2016). Semakin banyak foto yang ada maka semakin ingin CEO menunjukkan status dan posisinya dalam perusahaan karena tidak ingin kehilangan posisinya tersebut (Septriani \& Handayani, 2018). Kekuasaan yang dimiliki CEO juga dapat memunculkan sifat arogan karena menganggap tidak ada orang yang mampu menghentikan tindakannya termasuk kebijakan pengendalian internal perusahaan (Agusputri \& Sofie, 2019). Hal ini sesuai dengan hasil penelitian Apriliana dan Agustina (2017) yaitu jumlah foto CEO dalam laporan keuangan berpengaruh positif terhadap kecurangan laporan keuangan. Berdasarkan uraian di atas dapat diperoleh hipotesis:

$\boldsymbol{H}_{\text {9: }}$ Jumlah foto CEO (frequent number of CEO's picture) berpengaruh positif terhadap kecurangan laporan keuangan. 


\section{Model Penelitian}
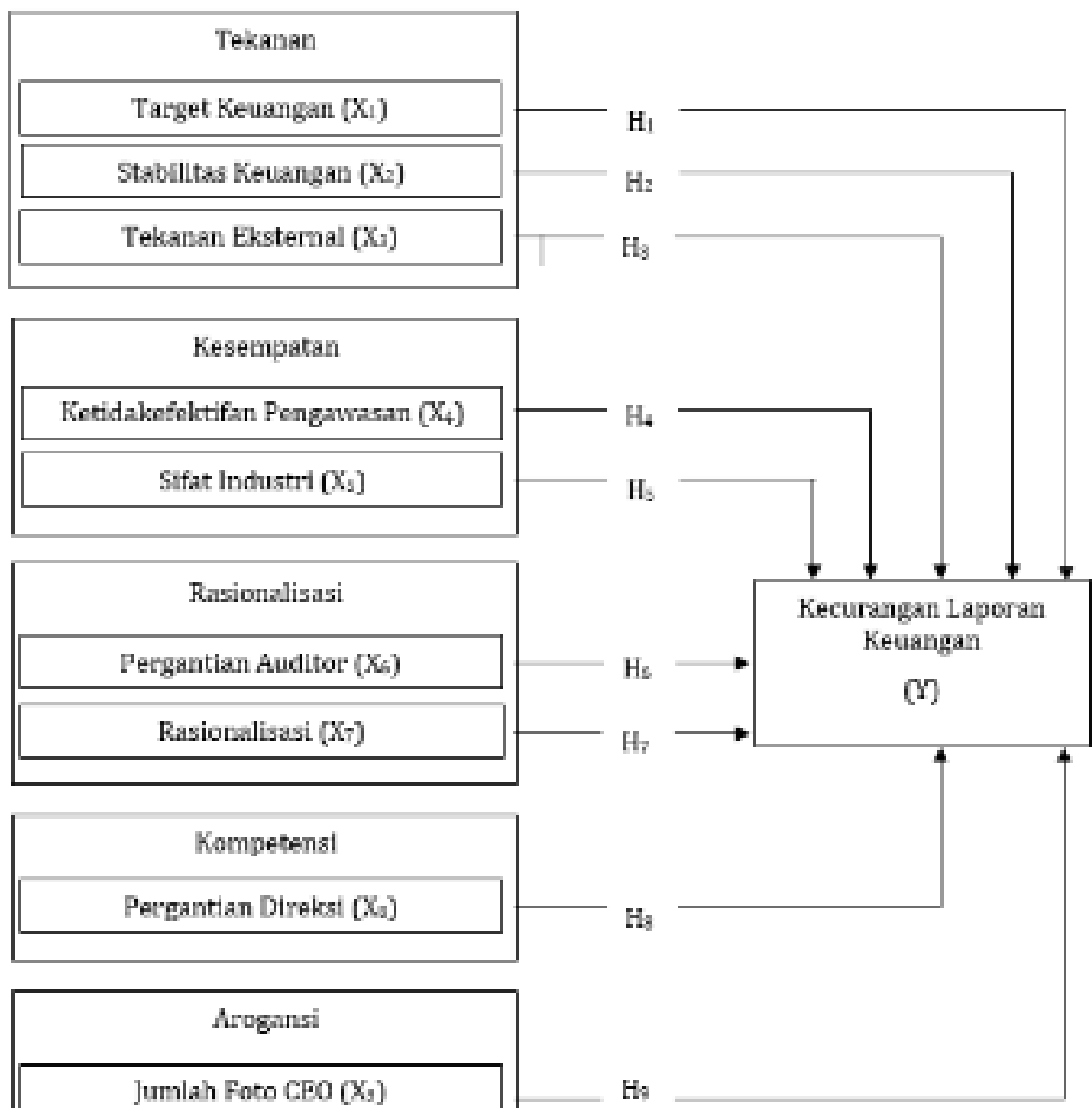

Jumlah Foto CEO $\left(\mathrm{X}_{3}\right)$

\section{Gambar 3. Model Penelitian}

\section{Metoda}

\section{Jenis dan Sumber Data}

Penelitian ini adalah penelitian yang menggunakan metode kuantitatif. Dalam penelitian ini terdapat sembilan variabel independen dan satu variabel dependen. Variabel independen terdiri dari target keuangan, stabilitas keuangan, tekanan eksternal, ketidakefektifan pengawasan, sifat industri, pergantian auditor, rasionalisasi, pergantian direksi, dan jumlah foto CEO. Variabel dependennya adalah kecurangan laporan keuangan.

Jenis data yang digunakan dalam penelitian ini adalah data sekunder yaitu laporan keuangan tahunan dari perusahaan yang diperoleh melalui website BEI dan website perusahaan yang dijadikan sampel. Penelitian ini mengambil populasi perusahaan pertambangan yang terdaftar di BEI selama periode 2016-2018. Teknik 
pengumpulan sampel yang digunakan adalah purposive sampling dengan kriteria sebagai berikut : perusahaan sektor pertambangan yang sudah terdaftar di BEI selama periode 2016-2018; perusahaan mempublikasikan laporan keuangan tahunannya yang telah diaudit dalam website BEI atau website perusahaan selama periode 2016-2018 dan satuannya dinyatakan dalam Rupiah; perusahaan tidak terkena delisting atau penghapusan pencatatan saham oleh BEI selama periode 20162018; dan data yang berkaitan dengan variabel yang digunakan dalam penelitian ini tersedia dengan lengkap dalam laporan keuangan tahunan perusahaan yang terdaftar di BEI selama periode 2016-2018.

\section{Pengukuran Variabel}

\section{Tabel 1. Pengukuran Variabel}

\begin{tabular}{|c|c|}
\hline Nama Variabel & Pengukuran \\
\hline Kecurangan & Nilai Discretionary Accrual \\
\hline $\begin{array}{l}\text { laporan keuangan } \\
\text { (Y) }\end{array}$ & $\begin{array}{l}D_{A C C_{i t}} \\
=\text { Total akrual perusahaan }{\text { pada } \text { tahun }_{t}}\end{array}$ \\
\hline $\begin{array}{l}\text { Target keuangan } \\
\qquad\left(\mathrm{X}_{1}\right)\end{array}$ & $\begin{array}{c}=\frac{\text { Total aset perusahaan }}{i} \text { pada } \text { tahun }_{t-1} \\
- \text { nondiscretionary accrual perusahaan }_{i} \text { pada tahun } \\
\text { Rasio profitabilitas } \\
R O A=\frac{\text { Laba bersih }}{\text { Total aset }}\end{array}$ \\
\hline Stabilitas & Rasio perubahan aset \\
\hline keuangan $\left(\mathrm{X}_{2}\right)$ & 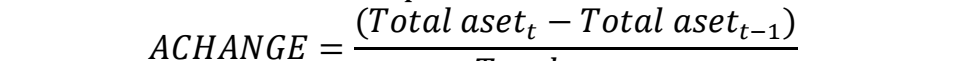 \\
\hline $\begin{array}{l}\text { Tekanan eksternal } \\
\qquad\left(\mathrm{X}_{3}\right)\end{array}$ & $\begin{array}{c}\text { Total aset }_{t-1} \\
\text { Rasio leverage } \\
\text { Total liabilitas }\end{array}$ \\
\hline $\begin{array}{l}\text { Ketidakefektifan } \\
\text { pengawasan }\left(\mathrm{X}_{4}\right)\end{array}$ & $\begin{array}{l}\text { REV }=\frac{\text { Total aset }}{\text { Rasio jumlah dewan komisaris independen }} \\
\text { Jumlah dewan komisaris independen }\end{array}$ \\
\hline Sifat industri $\left(\mathrm{X}_{5}\right)$ & $\begin{array}{l}\text { Jumlah total dewan komisaris } \\
\text { Rasio total piutang } \\
\text { Total piutang } \text { Total piutang }_{t-1} \text { Tot }\end{array}$ \\
\hline $\begin{array}{l}\text { Pergantian } \\
\text { auditor }\left(\mathrm{X}_{6}\right)\end{array}$ & $\begin{array}{c}\text { RECEIVABLE }=\frac{\text { Penjualan }_{t}}{\text { Menggunakan variabel dummy, jika terdapat pergantian }_{\text {denjualan }}} \\
\text { auditor selama periode } 2016-2018 \text { maka diberi kode } 1 \text {, namun } \\
\text { jika tidak diberi kode } 0\end{array}$ \\
\hline Rasionalisasi $\left(\mathrm{X}_{7}\right)$ & Rasio Total Akrual per Total Aset \\
\hline & $\begin{array}{l}\text { TATA } \\
=\frac{\Delta \text { Modal kerja }-\Delta \text { Kas }-\Delta \text { Hutang pajak lancar }-\Delta \text { Bebanc }}{}\end{array}$ \\
\hline $\begin{array}{l}\text { Pergantian direksi } \\
\qquad\left(\mathrm{X}_{8}\right)\end{array}$ & $\begin{array}{c}\text { Total aset } \\
\text { Menggunakan variabel dummy, jika terdapat pergantian } \\
\text { direksi selama periode } 2016-2018 \text { maka diberi kode } 1 \text {, namun } \\
\text { jika tidak diberi kode } 0\end{array}$ \\
\hline $\begin{array}{l}\text { Jumlah foto CEO } \\
\qquad\left(\mathrm{X}_{9}\right)\end{array}$ & $\begin{array}{l}\text { Jumlah foto CEO yang terdapat pada laporan keuangan } \\
\text { tahunan }\end{array}$ \\
\hline
\end{tabular}

Sumber: Data Diolah (2020) 


\section{Teknik Analisis Data}

Hipotesis diuji menggunakan model regresi linear berganda untuk menguji pengaruh variabel independen terhadap variabel dependen. Namun sebelumnya dilakukan uji asumsi klasik terlebih dahulu yaitu uji multikolinearitas. Adapun model regresi linier berganda yang digunakan dalam penelitian ini adalah sebagai berikut:

DACCit $=\beta_{0 \mathrm{it}}+\beta_{1}$ ROA $_{\mathrm{it}}+\beta_{2}$ ACHANGE $_{\mathrm{it}}+\beta_{3} \mathrm{LEV}_{\mathrm{it}}+\beta_{4}$ BDOUT $_{\mathrm{it}}+\beta_{5}$ RECEIVABLE $_{\mathrm{it}}+\beta_{6} \mathrm{CPA}_{\mathrm{it}}+\beta$

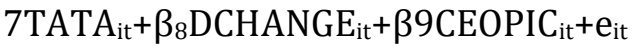

Keterangan:

$\begin{array}{ll}\beta_{0} & =\text { Konstanta } \\ \beta_{1}-\beta_{9} & =\text { Koefisien regresi } \\ \text { DACC }_{\text {it }} & =\text { Nilai Discretionary Accrual perusahaan i pada tahun t } \\ \text { ROA } & =\text { Return on Asset } \\ \text { ACHANGE } & =\text { Rasio perubahan total aset } \\ \text { LEV } & =\text { Rasio total liabilitas per total aset } \\ \text { BDOUT } & =\text { Rasio dewan komisaris independen } \\ \text { RECEIVABLE } & =\text { Rasio perubahan piutang } \\ \text { CPA } & =\text { Pergantian auditor independen } \\ \text { TATA } & =\text { Rasio total akrual per total aset } \\ \text { DCHANGE } & =\text { Pergantian direksi } \\ \text { CEOPIC } & =\text { Jumlah foto CEO } \\ \text { It } & =\mathrm{i}: \text { cross section, t: time } \\ \mathrm{e} & =\text { Error term }\end{array}$

\section{Hasil dan Pembahasan}

\section{Hasil}

\section{Statistik Deskriptif}

Jumlah populasi yang diperoleh pada penelitian ini adalah 48 perusahaan sektor pertambangan. Dari jumlah tersebut diperoleh 13 perusahaan yang memenuhi syarat untuk dijadikan sampel. Sebelum dilakukan pengujian lebih lanjut, disajikan terlebih dahulu hasil statistika deskriptif yang memberikan deskripsi atau gambaran mengenai karakteristik variabel-variabel yang digunakan dalam penelitian yang terdiri dari rata-rata, standar deviasi, minimum, dan maksimum.

\section{Tabel 2. Statistika Deskriptif}

\begin{tabular}{cccccc}
\hline Variable & Obs & Mean & Std. Dev. & Min & Max \\
\hline ROA & 39 & -0.0730 & 0.6380 & -3.9332 & 0.2119 \\
ACHANGE & 39 & 0.3269 & 1.5786 & -0.8147 & 9.7438 \\
LEV & 39 & 0.5125 & 0.1956 & 0.0334 & 1.0682 \\
BDOUT & 39 & 0.4120 & 0.0811 & 0.3333 & 0.6000 \\
RECEIVABLE & 39 & 0.0090 & 1.0084 & -3.1575 & 4.4422 \\
CPA & 39 & 0.2308 & 0.4268 & 0.0000 & 1.0000 \\
TATA & 39 & -0.2023 & 0.2157 & -0.4780 & 0.5574 \\
DCHANGE & 39 & 0.5128 & 0.5064 & 0.0000 & 1.0000 \\
CEOPIC & 39 & 5.3846 & 7.0845 & 1.0000 & 30.0000 \\
\hline
\end{tabular}

Sumber: Data Diolah (2020) 


\section{Uji Estimasi Model Data Panel}

Data yang digunakan dalam penelitian ini merupakan data panel sehingga perlu dilakukan pengujian terlebih dahulu untuk memilih model regresi data panel yang akan digunakan yaitu antara Common Effect Model (CEM), Fixed Effect Model (FEM), dan Random Effect Model (REM). Berikut ini tabel hasil uji chow, uji breusch and pagan lagrangian multiplier (BPLM), dan uji hausman.

\section{Tabel 3. Hasil Uji Estimasi Model Data Panel}

\begin{tabular}{ccc}
\hline Test & Prob. & Model Estimasi Terbaik \\
\hline Uji Chow & 0.0000 & FEM \\
Uji BPLM & 0.0000 & REM \\
Uji Hausman & 0.9623 & REM \\
\hline
\end{tabular}

Sumber: Data Diolah (2020)

\section{Uji Multikolinearitas}

Tabel 4 berikut ini merupakan hasil dari uji multikolinearitas antar variabel independen. Hasil angka yang ditunjukkan tidak ada yang lebih dari 0.75 sehingga tidak ada korelasi antar variabel independen.

Tabel 4. Hasil Uji Multikolinearitas

\begin{tabular}{cccccccccc}
\hline & ROA & $\begin{array}{c}\text { ACHA } \\
\text { NGE }\end{array}$ & $\begin{array}{c}\text { LEV } \\
\text { RDO }\end{array}$ & $\begin{array}{c}\text { RECEIV } \\
\text { ABLE }\end{array}$ & CPA & TATA & $\begin{array}{c}\text { DCH } \\
\text { ANGE }\end{array}$ & $\begin{array}{c}\text { CEO } \\
\text { PIC }\end{array}$ \\
\hline ROA & 1.00 & & & & & & & & \\
ACHANGE & 0.11 & 1.00 & & & & & & & \\
LEV & - & -0.36 & 1.00 & & & & & & \\
& 0.48 & & & & & & & & \\
BDOUT & - & 0.17 & 0.05 & 1.00 & & & & & \\
& 0.20 & & & & & & & & \\
RECEIVABLE & - & -0.11 & - & 0.14 & 1.00 & & & & \\
& 0.22 & & 0.05 & & & & & & \\
CPA & - & -0.12 & 0.08 & - & 0.05 & 1.00 & & & \\
& 0.29 & & & 0.15 & & & & \\
TATA & 0.16 & 0.003 & - & 0.24 & -0.04 & - & 1.00 & & \\
& & & 0.08 & & & 0.15 & & & \\
DCHANGE & 0.17 & 0.19 & - & 0.06 & -0.21 & - & 0.17 & 1.00 & \\
& & & 0.28 & & & 0.19 & & & \\
CEOPIC & 0.11 & -0.10 & - & - & -0.02 & - & -0.11 & 0.07 & 1.00 \\
& & & 0.26 & 0.13 & & 0.19 & & & \\
\hline
\end{tabular}

Sumber: Data Diolah (2020)

\section{Uji Hipotesis}

Hipotesis diuji menggunakan regresi linear berganda untuk data panel dengan model yang terpilih adalah REM. Data disajikan dalam jutaan Rupiah. Pada hasil pengujian diperoleh R Square sebesar 0.0374 yang artinya variabel independen mampu menjelaskan perubahan pada variabel dependen sebesar 0.0374 atau 3.74 persen, sedangkan sisanya dijelaskan oleh variabel lain di luar model. Untuk konstanta diperoleh hasil sebesar 0.0343 yang berarti bahwa besarnya jumlah DACC yang disebabkan oleh variabel lain selain variabel independen adalah sebesar 0.0343 atau 3.43 persen. 
Tabel 5. Hasil Uji Hipotesis

\begin{tabular}{cccc}
\hline Rsquare $=0.0374$ & & & \\
DACC & Coef. & Std. Err. & $\mathrm{P}>|\mathrm{z}|$ \\
ROA & 0.1469 & 0.0143 & 0.0000 \\
ACHANGE & -0.0004 & 0.0089 & 0.9610 \\
LEV & 0.1798 & 0.2708 & 0.5070 \\
BDOUT & -0.3945 & 0.2733 & 0.1490 \\
RECEIVABLE & 0.0376 & 0.0180 & 0.0370 \\
CPA & 0.0591 & 0.0272 & 0.0300 \\
TATA & 0.0472 & 0.0917 & 0.6070 \\
DCHANGE & 0.0354 & 0.0451 & 0.4320 \\
CEOPIC & 0.0029 & 0.0065 & 0.6510 \\
_cons & 0.0343 & 0.1405 & 0.8070 \\
\hline
\end{tabular}

Sumber: Data Diolah (2020)

\section{Pengaruh Target Keuangan terhadap Kecurangan Laporan Keuangan}

Faktor tekanan dalam fraud pentagon diproksikan dengan tiga variabel, yang pertama adalah target keuangan. Target keuangan dihitung menggunakan rasio profitabilitas yaitu Return on Asset (ROA). Pada hasil pengujian hipotesis untuk ROA diperoleh koefisien 0.1469 dan $\mathrm{P}>|\mathrm{z}|<\alpha 0.05$ yaitu 0.0000 sehingga ROA berpengaruh positif dan signifikan terhadap DACC. Setiap terjadi kenaikan ROA sebesar Rp1.000.000 maka akan meningkatkan DACC sebesar 0.1469. Oleh karena itu hipotesis pertama $\left(\mathrm{H}_{1}\right)$ diterima. Hal ini sejalan dengan hasil penelitian Agusputri dan Sofie (2019) serta Septriani dan Handayani (2018) yang menyatakan bahwa target keuangan berpengaruh positif terhadap kecurangan laporan keuangan. Perusahaan yang memiliki ROA tinggi mampu menghasilkan laba yang tinggi dan cenderung menargetkan laba yang lebih tinggi lagi pada periode selanjutnya. Kenaikan target keuangan ini dapat menjadi tekanan bagi manajemen sehingga terdorong untuk melakukan kecurangan laporan keuangan supaya target yang telah ditetapkan tersebut dapat terpenuhi (Septriani \& Handayani, 2018).

\section{Pengaruh Stabilitas Keuangan terhadap Kecurangan Laporan Keuangan}

Variabel yang kedua untuk memproksi tekanan adalah stabilitas keuangan. Pada penelitian ini stabilitas keuangan dihitung menggunakan rasio perubahan aset (ACHANGE). Berdasarkan hasil uji hipotesis diperoleh hasil koefisien sebesar - 0.0004 dan $\mathrm{P}>|\mathrm{z}|>\alpha 0.05$ yaitu 0.9610, sehingga tidak signifikan dan hipotesis kedua $\left(\mathrm{H}_{2}\right)$ ditolak. Stabilitas keuangan berpengaruh negatif dan tidak signifikan terhadap kecurangan laporan keuangan. Aset dapat digunakan untuk menggambarkan seberapa besar kekayaan yang dimiliki perusahaan. Kondisi perusahaan yang tidak stabil dapat terjadi jika perubahan total aset terlalu tinggi atau terlalu rendah karena manajemen tidak dapat mengelola aset dengan baik (Septriani \& Handayani, 2018). Namun kondisi keuangan yang tidak stabil tidak menjadi tekanan bagi manajemen untuk memanipulasi laporan keuangan perusahaan karena hal tersebut kemungkinan akan semakin memperburuk kondisi keuangan perusahaan kedepannya. Hasil penelitian ini sesuai dengan penelitian Arisandi dan Verawaty 
(2017) yang mendapat hasil bahwa stabilitas keuangan tidak memiliki pengaruh terhadap kecurangan laporan keuangan.

\section{Pengaruh Tekanan Eksternal terhadap Kecurangan Laporan Keuangan}

Variabel ketiga yang memproksi tekanan adalah tekanan eksternal yang dihitung menggunakan rasio leverage (LEV). Hasil hipotesis ketiga $\left(\mathrm{H}_{3}\right)$ ditolak karena hasil yang diperoleh menunjukkan $\mathrm{P}>|\mathrm{z}|>\alpha 0.05$ yaitu -0.5070 sehingga pengaruhnya tidak signifikan. Adapun koefisien yang diperoleh adalah sebesar 0.1798 sehingga dapat dikatakan tekanan eksternal tidak mempengaruhi kecurangan laporan keuangan. Hasil yang sama juga terdapat pada penelitian Septriani dan Handayani (2018), Apriliana dan Agustina (2017) serta Bawakes et al. (2018) bahwa tekanan eksternal tidak berpengaruh signifikan terhadap kecurangan laporan keuangan. Tekanan eksternal berupa risiko kredit akibat banyaknya pinjaman/hutang terhadap pihak eksternal tidak menjadi tekanan bagi perusahaan untuk melakukan kecurangan laporan keuangan. Hal ini bisa jadi karena perusahaan mampu melunasi hutang yang dimiliki.

\section{Pengaruh Ketidakefektifan Pengawasan terhadap Kecurangan Laporan Keuangan}

Faktor kedua yang terdapat dalam fraud pentagon adalah kesempatan yang diproksikan dengan ketidakefektifan pengawasan dan sifat industri. Ketidakefektifan pengawasan dihitung menggunakan proporsi antara jumlah dewan komisaris independen dengan jumlah total dewan komisaris yang ada di perusahaan (BDOUT). Berdasarkan hasil pengujian hipotesis diperoleh koefisien untuk BDOUT sebesar 0.3945 dan $\mathrm{P}>|\mathrm{z}|>\alpha 0.05$ yaitu 0.1490 sehingga tidak signifikan. Maka hipotesis keempat $\left(\mathrm{H}_{4}\right)$ ditolak karena ketidakefektifan pengawasan berpengaruh negatif dan tidak signifikan terhadap kecurangan laporan keuangan. Hal ini sejalan dengan hasil penelitian Yesiariani dan Rahayu (2017) serta Septriani \& Handayani (2018). Kecurangan dapat diminimalisir dengan adanya pengawasan yang efektif. Namun dalam penelitian ini semakin banyak dewan komisaris independen belum tentu menjamin bahwa pengawasan akan berjalan dengan efektif (Yesiariani \& Rahayu, 2017).

\section{Pengaruh Sifat Industri terhadap Kecurangan Laporan Keuangan}

Variabel sifat industri memproksi faktor kesempatan dan dihitung menggunakan rasio perubahan piutang (RECEIVABLE). Pada koefisien diperoleh angka sebesar 0.0376 dan $\mathrm{P}>|\mathrm{z}|<\alpha 0.05$ yaitu 0.0370 sehingga signifikan. Oleh karena itu hipotesis kelima $\left(\mathrm{H}_{5}\right)$ diterima, sifat industri berpengaruh positif terhadap kecurangan laporan keuangan. Setiap terjadi kenaikan piutang perusahaan sebesar Rp1.000.000 maka DACC akan bertambah sebesar 0.0376. Hal tersebut sejalan dengan penelitian Sihombing dan Rahardjo (2014) serta Indriani dan Terzaghi (2017). Jumlah piutang yang tinggi pada perusahaan menyebabkan jumlah kas yang dapat digunakan untuk kegiatan operasionalnya menjadi sedikit (Sihombing \& Rahardjo, 2014). Hal ini dapat mendorong pihak manajemen untuk melakukan kecurangan laporan keuangan supaya menarik investor. 


\section{Pengaruh Pergantian Auditor terhadap Kecurangan Laporan Keuangan}

Faktor rasionalisasi yang pertama diproksikan dengan pergantian auditor (CPA) yang dihitung menggunakan variabel dummy. Berdasarkan pengujian hipotesis diperoleh koefisien sebesar 0.0591 dan $\mathrm{P}>|\mathrm{z}|<\alpha 0.05$ yaitu 0.0300 , maka hipotesis keenam $\left(\mathrm{H}_{6}\right)$ diterima, pergantian auditor berpengaruh positif dan signifikan terhadap kecurangan laporan keuangan. Setiap terjadi pergantian auditor maka DACC akan bertambah sebesar 0.0591. Hasil tersebut sesuai dengan penelitian Faradiza dan Suyanto (2017) serta Wahyuni dan Budiwitjaksono (2017) bahwa pergantian auditor berpengaruh positif terhadap kecurangan laporan keuangan. Perusahaan mengganti auditornya bisa jadi untuk mengurangi pendeteksian adanya kecurangan laporan keuangan oleh auditor lama.

\section{Pengaruh Rasionalisasi terhadap Kecurangan Laporan Keuangan}

Variabel rasionalisasi dihitung menggunakan rasio total akrual per total aset (TATA). Koefisien yang diperoleh untuk variabel rasionalisasi adalah 0.0472 dan $P>|z|>\alpha$ 0.05 yaitu 0.6070 sehingga tidak signifikan. Hipotesis ketujuh $\left(\mathrm{H}_{7}\right)$ ditolak karena rasionalisasi berpengaruh positif namun tidak signifikan terhadap kecurangan laporan keuangan. Hasil ini sejalan dengan penelitian Septriani dan Handayani (2018) bahwa rasionalisasi tidak berpengaruh pada kecurangan laporan keuangan perusahaan manufaktur. Besarnya total akrual suatu perusahaan tergantung dari keputusan yang dibuat manajemen (Sihombing \& Rahardjo, 2014). Akan tetapi dalam penelitian ini nilai akrual tidak digunakan oleh pihak manajemen untuk memanipulasi laporan keuangan, namun untuk menunjukkan kinerja dan posisi keuangan perusahaan berdasarkan transaksi yang ada (Septriani \& Handayani, 2018).

\section{Pengaruh Pergantian Direksi terhadap Kecurangan Laporan Keuangan}

Faktor kompetensi dalam fraud pentagon diproksikan dengan pergantian direksi (DCHANGE) yang dihitung menggunakan variabel dummy. Hasil dari uji hipotesis menunjukkan koefisien DCHANGE sebesar 0.0354 dan $\mathrm{P}>|\mathrm{z}|>\alpha 0.05$ yaitu 0.4320 . Berdasarkan hal tersebut maka pergantian direksi berpengaruh positif namun tidak signifikan terhadap kecurangan laporan keuangan sehingga hipotesis kedelapan $\left(\mathrm{H}_{8}\right)$ ditolak. Penelitian Sihombing dan Rahardjo (2014), Bawakes et al. (2018) serta Indriani dan Terzaghi (2017) juga memperoleh hasil yang sama bahwa pergantian direksi memiliki pengaruh dengan arah positif terhadap kecurangan laporan keuangan. Umumnya pada suatu perusahaan pergantian direksi dilakukan supaya memperoleh direksi baru yang lebih kompeten dari direksi sebelumnya (Septriani \& Handayani, 2018). Namun hasil pada penelitian ini menunjukkan bahwa perusahaan melakukan pergantian direksi karena direksi baru yang lebih kompeten diharapkan dapat meningkatkan kinerja perusahaan menjadi lebih baik dan bukan untuk mengurangi adanya kecurangan laporan keuangan (Annisya, 2016).

\section{Pengaruh Jumlah Foto CEO terhadap Kecurangan Laporan Keuangan}

Faktor dalam fraud pentagon yang terakhir adalah arogansi. Dalam penelitian ini arogansi diproksikan dengan jumlah foto CEO yang terdapat dalam laporan tahunan 
perusahaan. Hasil dari uji hipotesis menunjukan koefisien sebesar 0.0029 dan $\mathrm{P}>|\mathrm{z}|$ $>\alpha 0.05$ yaitu 0.6510. Berdasarkan hal tersebut maka jumlah foto CEO berpengaruh positif namun tidak signifikan terhadap kecurangan laporan keuangan, sehingga hipotesis kesembilan $\left(\mathrm{H}_{9}\right)$ ditolak. Hasil ini sejalan dengan penelitian Agusputri dan Sofie (2019) bahwa jumlah foto CEO tidak menggambarkan arogansi CEO. Foto CEO yang terdapat dalam laporan tahunan perusahaan bertujuan untuk memperkenalkan pemimpin perusahaan dan banyaknya foto tersebut adalah hasil dokumentasi dari kegiatan-kegiatan yang diikuti perusahaan (Agusputri \& Sofie, 2019).

\section{Simpulan}

Penelitian ini bertujuan untuk menguji pengaruh faktor-faktor fraud pentagon yang terdiri dari tekanan, kesempatan, rasionalisasi, kompetensi, dan arogansi untuk mendeteksi kemungkinan terjadinya kecurangan laporan keuangan pada perusahaan pertambangan yang terdaftar di BEI selama periode 2016-2018. Terdapat populasi sebanyak 48 perusahaan pertambangan dan dari jumlah tersebut diperoleh 13 perusahaan yang memenuhi syarat untuk dijadikan sampel.

Berdasarkan hasil pengujian hipotesis, untuk faktor tekanan variabel target keuangan memiliki pengaruh positif terhadap kemungkinan terjadinya kecurangan laporan keuangan. Namun variabel stabilitas keuangan dan tekanan eksternal tidak berpengaruh terhadap kecurangan laporan keuangan. Faktor kedua yaitu kesempatan memperoleh hasil ketidakefektifan pengawasan tidak berpengaruh, sedangkan sifat industri berpengaruh positif terhadap kecurangan laporan keuangan. Untuk faktor rasionalisasi, pergantian auditor berpengaruh positif terhadap kemungkinan terjadinya kecurangan laporan keuangan, sedangkan rasionalisasi tidak berpengaruh. Faktor keempat yaitu kompetensi yang diproksikan dengan pergantian direksi dan faktor kelima yaitu arogansi yang diproksikan dengan jumlah foto CEO terbukti tidak berpengaruh terhadap kecurangan laporan keuangan.

Penelitian ini memiliki beberapa keterbatasan. Rentang waktu pengamatan dalam penelitian ini hanya tiga periode laporan keuangan. Adapun nilai R Square yang diperoleh adalah 0.0374 sehingga variabel independen hanya mampu menjelaskan perubahan pada variabel dependen sebesar 3.74 persen. Selain itu jumlah sampel pada penelitian ini hanya 13 perusahaan pertambangan sehingga kurang mampu merepresentasikan populasi yang ada.

Berdasarkan keterbatasan yang telah diuraikan, terdapat beberapa saran untuk penelitian selanjutnya. Pertama, diharapkan penelitian selanjutnya dapat memperluas rentang waktu pengamatan laporan keuangan misalnya menjadi lima tahun. Kedua, diharapkan dapat menggunakan objek perusahaan sektor industri lain yang masih belum banyak diteliti. Apabila sampel yang diperoleh terlalu sedikit maka dapat memperkecil kriteria sampel. Ketiga, penelitian selanjutnya dapat menggunakan alternatif pengukuran lain selain manajemen laba untuk memproksi kecurangan laporan keuangan supaya dapat memberikan keberagaman dan dapat dijadikan perbandingan dengan penelitian selanjutnya. 


\section{Daftar Pustaka}

ACFE Indonesia Chapter \#111. (2016). Survai fraud Indonesia, Association of Certified Fraud Examiners (ACFE). https://doi.org/10.1201/9781315178141-3

Agusputri, H. dan Sofie. (2019). Faktor - faktor yang berpengaruh terhadap fraudulent financial reporting dengan menggunakan analisis fraud pentagon. Jurnal Informasi, Perpajakan, Akuntansi, Dan Keuangan Publik, 14(2), 105. https://doi.org/10.25105/jipak.v14i2.5049

Albrecht, W. S., Albrecht, C. O., Albretch, C. C., \& Zimbelman, M. F. (2012). Fraud Examination. In Boston, MA: Cengage Learning (4th Edition).

Annisya, M., Lindrianasari, \& Asmaranti, Y. (2016). Pendeteksian kecurangan laporan keuangan menggunakan fraud diamond. Jurnal Bisnis Dan Ekonomi (JBE), 23(1), 72-89.

Apriliana, S., \& Agustina, L. (2017). The analysis of fraudulent financial reporting determinant through fraud pentagon approach. Jurnal Dinamika Akuntansi, 9(2), 154-165. https://doi.org/10.15294/jda.v7i1.4036

Arisandi, D., \& Verawaty. (2017). Fraud pentagon dalam mendeteksi kecurangan laporan keuangan pada perusahaan keuangan dan perbankan di indonesia. Seminar Nasional Global Competitive Advantage, 3, 312-323.

Artani, K. T. B., \& Wetra, I. W. (2017). Pengaruh academic self efficacy dan fraud diamond terhadap perilaku kecurangan akademik mahasiswa akuntansi di Bali. Jurnal Riset Akuntansi, 7(2), 123-132.

Bawakes, H. F., Simanjuntak, A. M., \& Daat, S. C. (2018). Pengujian teori fraud pentagon terhadap fraudulent financial reporting. Jurnal Akuntansi \& Keuangan Daerah, 13(1), $114-134$

Cressey, D. R. (1953). Other People's Money. Montclair, NJ: Patterson Smith, 1-300.

Dechow, P. M., Sloan, R. G., Sweeney, A. P., Sloan, R. G., \& Sweeney, A. P. (2015). Detecting earnings management. Asian Financial Statement Analysis, 70(2), 73-105. https://doi.org/10.1002/9781119204763.ch4

Dorris, B., Examiners, F., \& Dorris, B. (2020). Report to the Nations: Global Study on Occupational Fraud and Abuse. In Association of Certified Fraud Examiners. Diunduh dari https://www.acfe.com/report-to-the-nations/2020/

Faradiza, S. A., \& Suyanto. (2017). Fraud diamond: Pendeteksi kecurangan laporan keuangan. Seminar Nasional Riset Terapan 2017, 196-201.

Halim, D. (2020). 5 fakta baru kasus Jiwasraya, laba semu hingga janji Jaksa Agung ungkap tersangka. Diakses pada 1 Juli 2020, dari https://nasional.kompas.com/read/2020/01/09/07172091/5-fakta-baru-kasusjiwasraya-laba-semu-hingga-janji-jaksa-agung-ungkap?page=all

Handoko, B. L., \& Ramadhani, K. A. (2017). Pengaruh karakteristik komite audit, keahlian keuangan dan ukuran perusahaan terhadap kemungkinan kecurangan laporan keuangan. DeReMa Jurnal Manajemen, 12(1), 86-113. https://doi.org/10.19166/derema.v12i1.357

Horwath, C. (2011). Putting the Freud in Fraud: Why the fraud triangle is no longer enough. IN Horwath, Crowe.

Idris, M. (2020). Jejak hitam PT Hanson International, manipulasi laporan keuangan 2016. $\begin{array}{lllll}\text { Diakses } & \text { pada } & 1 & \text { Juli } & 2020,\end{array}$ https://money.kompas.com/read/2020/01/15/160600526/jejak-hitam-pt-hansoninternational-manipulasi-laporan-keuangan-2016?page=all

Indriani, P., \& Terzaghi, M. T. (2017). Fraund diamond dalam mendeteksi kecurangan laporan keuangan. I-Finance: A Research Journal on Islamic Finance, 3(2), 161. 
https://doi.org/10.19109/ifinance.v3i2.1690

Jensen, M. C., \& Meckling, W. H. (1976). Thery of the firm : Manajerial behavior, agency cost and owership structure. Journal of Financial Economics, 3, 305-360.

Jones, J. J. (1991). Earnings management during import relief investigations. Journal of Accounting Research, 29(2), 193. https://doi.org/10.2307/2491047

Karyono. (2013). Forensic Fraud. CV Andi Offset.

Kurnia, T. (2019). 7 fakta gonjang-ganjing laporan keuangan Garuda Indonesia. Diakses pada 1 Juli 2020, dari https://www.liputan6.com/bisnis/read/4000383/7-fakta-gonjangganjing-laporan-keuangan-garuda-indonesia

Kurniawansyah, D., Kurnianto, S., \& Rizqi, F. A. (2019). Teori agency dalam pemikiran organisasi ; Pendekatan positivist dan principle-agen. Jurnal Riset Akuntansi Dan Bisnis Airlangga, 3(2), 435-446. https://doi.org/10.31093/jraba.v3i2.122

Noble, M. R. (2019). Fraud diamond analysis in detecting financial statement fraud. The Indonesian Accounting Review, 9(2), 121-132. https://doi.org/10.14414/tiar.v9i2.1632

Pratiwi, H. R. (2019). Kronologi kisruh laporan keuangan Garuda Indonesia. Diakses pada 1 Juli 2020, dari https://www.cnnindonesia.com/ekonomi/20190430174733-92390927/kronologi-kisruh-laporan-keuangan-garuda-indonesia

Putriasih, K., Herawati, N. N. T., \& Wahyuni, M. A. (2019). Analisis fraud diamond dalam mendeteksi financial statement fraud: Studi empiris pada perusahaan manufaktur yang terdaftar di Bursa Efek Indonesia (BEI) tahun 2016 - 2018. Prosiding Seminar Nasional Cendekiawan, 1(3), 2. https://doi.org/10.25105/semnas.v0i0.5780

Selano, E. C. D., Tedjasuksmana, B., \& Wardani, R. P. (2017). Faktor-Faktor yang mempengaruhi kecenderungan kecurangan laporan keuangan pada perusahaan property, real estate and building yang terdaftar di BEI tahun 2013-2015. Jurnal Akuntansi Kontemporer, 162-182.

Septriani, Y., \& Handayani, D. (2018). Mendeteksi kecurangan laporan keuangan dengan analisis fraud pentagon. Jurnal Akuntansi, Keuangan Dan Bisnis, 11(1), 11-23.

Sihombing, K. S., \& Rahardjo, S. N. (2014). Pengaruh fraud diamond dalam mendeteksi financial statement fraud (studi empiris pada perusahaan ritel yang terdaftar di Bursa Efek Indonesia tahun 2014 - 2016). Diponegoro Journal of Accounting, 3, 1-12.

Tiffani, L., \& Marfuah. (2009). Deteksi financial statement fraud dengan analisis fraud triangel pada perusahaan manufaktur yang terdaftar di Bursa Efek Indonesia. Jurnal Akuntansi Dan Auditing Indonesia, 19(2), 112-125.

Ulya, F. N. (2020). Kasus Jiwaraya, beberkan juga peran akuntan. Diakses pada 1 Juli 2020, dari https://money.kompas.com/read/2020/01/09/135638726/kasus-jiwasrayabeberkan-juga-peran-akuntan

Wahyuni, \& Budiwitjaksono, G. S. (2017). Fraud triangle sebagai pendeteksi kecurangan laporan keuangan. Jurnal Akuntansi, 21(1), 47. https://doi.org/10.24912/ja.v21i1.133

Wilopo, R. (2014). Etik profesi akuntan: Kasus-kasus di Indonesia (Edisi Kedua). STIE Perbanas Press.

Wolfe, D., \& Hermanson, D. (2004). The fraud diamond: Considering the four elements of fraud. The CPA Journal, 74, 38-42.

Yesiariani, M., \& Rahayu, I. (2017). Deteksi financial statement fraud: Pengujian dengan fraud diamond. Jurnal Akuntansi \& Auditing Indonesia, 21(1), 49-60. https://doi.org/10.20885/jaai.vol21.iss1.art5

Yusof, K. M. (2016). Fraudulent financial reporting: An application of fraud models to malaysian public listed companies. Jarle, 9(5), 35. 